Wilfrid Laurier University

Scholars Commons @ Laurier

2000

\title{
Protective Effects of Calcium Against Chronic Waterborne Cadmium Exposure to Juvenile Rainbow Trout
}

\author{
Lydia Hollis \\ University of Calgary \\ James C. McGeer \\ Wilfrid Laurier University, jmcgeer@wlu.ca \\ D. Gordon McDonald \\ McMaster University \\ Chris M. Wood \\ McMaster University
}

Follow this and additional works at: https://scholars.wlu.ca/biol_faculty

\section{Recommended Citation}

Hollis, Lydia; McGeer, James C.; McDonald, D. Gordon; and Wood, Chris M., "Protective Effects of Calcium Against Chronic Waterborne Cadmium Exposure to Juvenile Rainbow Trout" (2000). Biology Faculty Publications. 29.

https://scholars.wlu.ca/biol_faculty/29

This Article is brought to you for free and open access by the Biology at Scholars Commons @ Laurier. It has been accepted for inclusion in Biology Faculty Publications by an authorized administrator of Scholars Commons @ Laurier. For more information, please contact scholarscommons@wlu.ca. 


\title{
PROTECTIVE EFFECTS OF CALCIUM AGAINST CHRONIC WATERBORNE CADMIUM EXPOSURE TO JUVENILE RAINBOW TROUT
}

\author{
Lydia Hollis, $* \dagger$ JAmes C. MCGeER, $\ddagger$ D. Gordon MCDonald, $\S$ and Chris M. Wood $\S$ \\ $\dagger$ Department of Biological Sciences, University of Calgary, 2500 University Drive North West, Calgary, Alberta T2N 1N4, Canada \\ †Environmental Laboratory, CANMET, 555 Booth Street, Room 328B, Ottawa, Ontario K1A 0G1, Canada \\ $\S$ Department of Biology, McMaster University, 1280 Main Street West, Hamilton, Ontario L8S 4K1, Canada
}

(Received 17 September 1999; Accepted 21 March 2000)

\begin{abstract}
Juvenile rainbow trout (Oncorhynchus mykiss [Walbaum]) on 1\% daily ration were exposed to 0 (control) or $2 \mu \mathrm{g}$ of cadmium as $\mathrm{Cd}\left(\mathrm{NO}_{3}\right)_{2}-4 \mathrm{H}_{2} \mathrm{O}$ per liter added to four different calcium (Ca) concentrations: 260 (background), 470 (low), 770 (medium), or 1200 (high) $\mu \mathrm{M}$ of $\mathrm{Ca}$ added as $\mathrm{Ca}\left(\mathrm{NO}_{3}\right)_{2}-4 \mathrm{H}_{2} \mathrm{O}$ in synthetic soft water for $30 \mathrm{~d}$. Mortality was highest $(\sim 80 \%)$ in the background + Cd treatment. Approximately $40 \%$ mortality was observed in the low + Cd exposure; mortality was $10 \%$ or less for all other treatments. No growth effects were seen for any of the exposures. Kidneys accumulated the greatest concentration of $\mathrm{Cd}$ during the $30 \mathrm{~d}$, followed by gills and livers. Accumulation of $\mathrm{Cd}$ in gills, kidney, and liver decreased at higher water $\mathrm{Ca}$ concentrations. No differences in whole-body or plasma Ca concentrations were found. Swimming performance was impaired in the low + Cd-exposed fish. Influx of $\mathrm{Ca}^{2+}$ into whole bodies decreased as water $\mathrm{Ca}$ concentrations increased; influx of $\mathrm{Ca}^{2+}$ into background $+\mathrm{Cd}$-treated fish was significantly reduced compared to that in control fish. Experiments that measured uptake of new $\mathrm{Cd}$ into gills showed that the affinity of gills for $\mathrm{Cd}\left(K_{\mathrm{Cd}-\mathrm{gill}}\right)$ and the number of binding sites for $\mathrm{Cd}$ decreased as water $\mathrm{Ca}$ concentrations increased. Acute accumulation of new $\mathrm{Cd}$ into gills and number of gill Cd-binding sites increased with chronic $\mathrm{Cd}$ exposure, whereas the affinity of gills for $\mathrm{Cd}$ decreased with chronic $\mathrm{Cd}$ exposure. Longer-term gill binding ( $72 \mathrm{~h}$ ) showed reduced uptake of new $\mathrm{Cd}$ at higher water $\mathrm{Ca}$ levels and increased uptake with chronic $\mathrm{Cd}$ exposure. Complications were found in applying the biotic ligand model to fish that were chronically exposed to $\mathrm{Cd}$ because of discrepancies in the maximum number of gill $\mathrm{Cd}$ binding sites among different studies.
\end{abstract}

Keywords-Cadmium Calcium Gill binding Modeling Rainbow trout

\section{INTRODUCTION}

Waterborne cadmium (Cd) can cause severe, acute toxicological and physiological effects to aquatic organisms. However, these effects can be altered by water hardness [1-6]. Carrol et al. [7], Pärt et al. [2], and McDonald et al. [8] have shown that protection against $\mathrm{Cd}$ uptake and acute toxicity in freshwater fish is related to the water concentration of calcium (Ca), rather than of magnesium $(\mathrm{Mg})$, illustrating that $\mathrm{Ca}$ is the primary cation responsible for the protective action of hard water. This protective action of $\mathrm{Ca}$ has been attributed to changes in gill permeability and/or competition between $\mathrm{Cd}$ and $\mathrm{Ca}$ for gill-binding sites [2,9-13].

The great majority of research has focused on acute $\mathrm{Cd}$ toxicity, but a number of studies have shown that $\mathrm{Cd}$ may cause sublethal deleterious effects during low-level, chronic exposures [14-20]. Water hardness is protective against chronic as well as acute $\mathrm{Cd}$ toxicity in freshwater fish [21], and a hardness correction has been incorporated into ambient waterquality criteria for chronic Cd exposures in Europe [22], the United States [23], and Canada [24]. The primary objective of the present study was to determine the mechanistic basis for the protective effects of $\mathrm{Ca}$ against chronic $\mathrm{Cd}$ exposure in juvenile rainbow trout. We examined changes in gill $\mathrm{Cd}$ burden and the acute Cd-binding properties of the gills accompanying 30-d exposure of trout in synthetic soft water supplemented with various $\mathrm{Ca}$ concentrations $(260,470,770$, or $1200 \mu \mathrm{M})$ in the presence or absence of $2 \mu \mathrm{g} \mathrm{Cd} / \mathrm{L}$. A

* To whom correspondence may be addressed (lmhollise@ucalgary.ca). particular focus was placing the gill-binding results into a biotic ligand modeling framework, which has recently been advocated for the generation of site-specific water-quality criteria [13,25-28]. Additional goals were to characterize Cd accumulation in other compartments (liver, kidney, and whole body) and to document possible sublethal effects as well as costs of chronic $\mathrm{Cd}$ exposure, as expressed in growth on submaximal ration, whole-body and plasma ion content, gill $\mathrm{Ca}^{2+}$ influx, and exercise performance.

\section{MATERIALS AND METHODS}

Fish holding conditions

Rainbow trout [Oncorhynchus mykiss (Walbaum)] were obtained from Humber Springs Trout Farm in Orangeville, Ontario, Canada, and were held in flowing dechlorinated Hamilton tap water (Lake Ontario water: $\mathrm{Ca}=40 \mathrm{mg} / \mathrm{L}$ or $1 \mathrm{mM}$, sodium $[\mathrm{Na}]=14 \mathrm{mg} / \mathrm{L}$ or $0.60 \mathrm{mM}$, chloride $[\mathrm{Cl}]=25 \mathrm{mg} /$ $\mathrm{L}$ or $0.70 \mathrm{mM}$, dissolved organic matter $[\mathrm{DOM}]=3 \mathrm{mg} / \mathrm{L}$ or $0.25 \mathrm{mM}$, hardness $=140 \mathrm{mg} / \mathrm{L}$ as $\mathrm{CaCO}_{3}$, alkalinity $=95$ $\mathrm{mg} / \mathrm{L}$ as $\mathrm{CaCO}_{3}, \mathrm{pH} 8.0,14^{\circ} \mathrm{C}$ ). Trout were held in $600-\mathrm{L}$ aerated polyethylene tanks for two months and then slowly introduced to synthetic soft water during the course of one week. The synthetic soft water $(\mathrm{Ca}=10 \mathrm{mg} / \mathrm{L}$ or $0.26 \mathrm{mM}$, $\mathrm{Na}=3 \mathrm{mg} / \mathrm{L}$ or $0.14 \mathrm{mM}, \mathrm{Cl}=4 \mathrm{mg} / \mathrm{L}$ or $0.10 \mathrm{mM}$, DOM $=0.40 \mathrm{mg} / \mathrm{L}$ or $0.03 \mathrm{mM}$, hardness $=20 \mathrm{mg} / \mathrm{L}$ as $\mathrm{CaCO}_{3}$, alkalinity $=15 \mathrm{mg} / \mathrm{L}$ as $\mathrm{CaCO}_{3}, \mathrm{pH} 7.2,13^{\circ} \mathrm{C}$ ) was produced by reverse osmosis (Anderson Water Systems, Dundas, ON, Canada) and consisted of one part dechlorinated Hamilton tap water added to six parts ion-reduced water produced by reverse osmosis. Fish were held in soft water for at least three weeks 
Table 1. Measured water chemistry parameters and mortality at $30 \mathrm{~d}$ for the eight exposure treatments. Means $\pm 1 \mathrm{SE}^{\mathrm{a}}(n=16)$

\begin{tabular}{|c|c|c|c|c|c|c|}
\hline \multirow[b]{2}{*}{ Treatment } & \multirow[b]{2}{*}{ Nominal concentration } & \multicolumn{4}{|c|}{ Measured chemistry } & \multirow{2}{*}{$\begin{array}{l}\text { Mortality } \\
\text { at } 30 \mathrm{~d}\end{array}$} \\
\hline & & $\mathrm{Ca}(\mu \mathrm{M})$ & $\mathrm{Cd}(\mu \mathrm{g} / \mathrm{L})$ & $\mathrm{Na}(\mu \mathrm{M})$ & $\mathrm{Cl}(\mu \mathrm{M})$ & \\
\hline Background & $260 \mu \mathrm{M} \mathrm{Ca}$ & $257 \pm 19$ & $0.08 \pm 0.06$ & $141 \pm 48$ & $111 \pm 52$ & $0 \%$ \\
\hline $\begin{array}{l}\text { Background } \\
\quad+\mathrm{Cd}\end{array}$ & $\begin{array}{l}260 \mu \mathrm{M} \mathrm{Ca} \\
\quad+2 \mu \mathrm{g} / \mathrm{L} \mathrm{Cd}\end{array}$ & $270 \pm 22$ & $3.00 \pm 0.02$ & $143 \pm 49$ & $112 \pm 55$ & $78 \%$ \\
\hline Low & $470 \mu \mathrm{M} \mathrm{Ca}$ & $445 \pm 20$ & $0.02 \pm 0.02$ & $140 \pm 47$ & $109 \pm 50$ & $1 \%$ \\
\hline $\begin{array}{l}\text { Low } \\
\qquad+\mathrm{Cd}\end{array}$ & $\begin{array}{l}470 \mu \mathrm{M} \mathrm{Ca} \\
\quad+2 \mu \mathrm{g} / \mathrm{L} \mathrm{Cd}\end{array}$ & $502 \pm 16$ & $3.20 \pm 0.20$ & $140 \pm 49$ & $111 \pm 51$ & $39 \%$ \\
\hline Medium & $770 \mu \mathrm{M} \mathrm{Ca}$ & $938 \pm 21$ & $0.09 \pm 0.09$ & $101 \pm 27$ & $66 \pm 33$ & $9 \%$ \\
\hline $\begin{array}{l}\text { Medium } \\
\quad+\mathrm{Cd}\end{array}$ & $\begin{array}{l}770 \mu \mathrm{M} \mathrm{Ca} \\
\quad+2 \mu \mathrm{g} / \mathrm{L} \mathrm{Cd}\end{array}$ & $602 \pm 108$ & $1.60 \pm 0.30$ & $104 \pm 28$ & $68 \pm 34$ & $7 \%$ \\
\hline High & $1200 \mu \mathrm{M} \mathrm{Ca}$ & $1235 \pm 73$ & $0.04 \pm 0.04$ & $103 \pm 28$ & $67 \pm 35$ & $7 \%$ \\
\hline $\begin{array}{l}\text { High } \\
\quad+\mathrm{Cd}\end{array}$ & $\begin{array}{l}1200 \mu \mathrm{M} \mathrm{Ca} \\
+2 \mu \mathrm{g} / \mathrm{L} \mathrm{Cd}\end{array}$ & $1218 \pm 128$ & $1.60 \pm 0.20$ & $96 \pm 22$ & $55 \pm 31$ & $10 \%$ \\
\hline
\end{tabular}

${ }^{a} \mathrm{SE}=$ standard error

before experimentation. Fish were fed $1 \%$ body weight per day (as one meal per day) with Martin's Starter Food (Martin Feed Mills, Elmira, ON, Canada; Cd content $=1.06 \pm 0.04$ $[n=6] \mu \mathrm{g} / \mathrm{g}[$ wet wt]).

\section{Exposure system}

After three weeks in holding tanks, 85 fish were randomly transferred to each of sixteen 200-L polyethylene exposure tanks, which were flowthrough systems (flow $=500 \mathrm{ml} / \mathrm{min}$ ) with continuous aeration. Fish were fed a submaximal ration of $1 \%$ body weight per day (discussed earlier), compared with a typical ration of $3 \%$ body weight per day [20], in the hope of revealing metabolic costs associated with chronic $\mathrm{Cd}$ exposure. An acidified $\mathrm{Cd}$ stock solution, with $\mathrm{Cd}$ added as $\mathrm{Cd}\left(\mathrm{NO}_{3}\right)_{2} \cdot 4 \mathrm{H}_{2} \mathrm{O}$, and a $\mathrm{Ca}$ stock solution, with $\mathrm{Ca}$ added as $\mathrm{Ca}\left(\mathrm{NO}_{3}\right)_{2} \cdot 4 \mathrm{H}_{2} \mathrm{O}$, were delivered to a mixing head-tank via mariotte bottles [29] to achieve the desired $\mathrm{Cd}$ and Ca concentrations in the exposure tanks. Tanks were spiked on the first day of exposure to instantly reach the desired $\mathrm{Cd}$ and $\mathrm{Ca}$ concentrations. Water chemistry was measured weekly throughout the exposure period. Unless otherwise noted, all chemicals were obtained from Fisher Scientific (Nepean, ON, Canada), and all radioisotopes were obtained from New England $\mathrm{Nu}-$ clear (Boston, MA, USA).

Fish were exposed to four concentrations of $\mathrm{Ca}$ in either the absence or the presence of $\mathrm{Cd}$ at a nominal concentration of approximately $2 \mu \mathrm{g} / \mathrm{L}$. This concentration was chosen based on an initial 96-h LC50 measurement of approximately $2 \mu \mathrm{g}$ $\mathrm{Cd} / \mathrm{L}$ in the background $\mathrm{Ca}$ concentration of $260 \mu \mathrm{M}$. Each of the eight treatment conditions had two replicates, so $n=$ 170 fish per treatment. The eight exposures (nominal concentrations) were (1) background Ca $(260 \mu \mathrm{M})$ with zero cadmium, (2) background $\mathrm{Ca}(260 \mu \mathrm{M})+2 \mu \mathrm{g} \mathrm{Cd} / \mathrm{L}$, (3) low $\mathrm{Ca}(470 \mu \mathrm{M})$ with no added $\mathrm{Cd}$, (4) low $\mathrm{Ca}(470 \mu \mathrm{M})+2$ $\mu \mathrm{g} \mathrm{Cd} / \mathrm{L}$, (5) medium $\mathrm{Ca}(770 \mu \mathrm{M})$ with no added $\mathrm{Cd}$, (6) medium Ca $(770 \mu \mathrm{M})+2 \mu \mathrm{g} \mathrm{Cd} / \mathrm{L}$, (7) high Ca $(1200 \mu \mathrm{M})$ with no added $\mathrm{Cd}$, and (8) high $\mathrm{Ca}(1200 \mu \mathrm{M})+2 \mu \mathrm{g} \mathrm{Cd} / \mathrm{L}$ for $30 \mathrm{~d}$ in synthetic soft water. Actual measured water $\mathrm{Ca}$ and $\mathrm{Cd}$ concentrations are presented in Table 1. Treatments are referred to as background, low, medium, and high $\mathrm{Ca}$, and as background $+\mathrm{Cd}$, low $+\mathrm{Cd}$, medium $+\mathrm{Cd}$, and high + $\mathrm{Cd}$.

\section{Sampling}

During the 30-d Cd exposure, 16-ml water samples were taken throughout the exposure period. These samples were acidified with $50 \mu \mathrm{l}$ of $\mathrm{HNO}_{3}$ and then analyzed for $\mathrm{Na}, \mathrm{Ca}$, $\mathrm{Cl}$, and total $\mathrm{Cd}$ content (Table 1). Fish from each treatment tank were bulk weighed every $10 \mathrm{~d}$, and specific growth rates were determined according to the procedure described by Hollis et al. [20].

Six fish from each tank were subsampled at days $0,2,10$, 20 , and 30 , and the gills, liver, kidney, and remaining carcass were assayed for $\mathrm{Cd}$ content. The remaining carcass was also assayed for whole-body ion content. Fish were sacrificed, and both sets of gills and the liver were excised. Gills were rinsed for $10 \mathrm{~s}$ in $100 \mathrm{ml}$ of dechlorinated Hamilton tap water. All tissues plus remaining carcasses were frozen until analysis of $\mathrm{Cd}$ and ion content. Six additional fish from each tank were also sampled at days $0,2,10,20$, and 30 for plasma Ca concentrations. Fish were sacrificed, and blood samples (40-285 $\mu \mathrm{l})$ were taken by caudal puncture with $1 \mathrm{~cm}^{3}$ syringes. Blood samples were centrifuged for $2 \mathrm{~min}$. The plasma was then removed, and the sample was stored at $-70^{\circ} \mathrm{C}$ until the analysis of $\mathrm{Ca}$ content.

\section{Testing}

Exercise performance. Fish were not fed on the day of swimming tests. Swimming performance was determined using the protocol of McDonald et al. [30], which is a stamina test that uses a fixed velocity $(60 \mathrm{~cm} / \mathrm{s} ; \sim 5$ body lengths $/ \mathrm{s})$ and exhaustion as the endpoint. Sprint times were corrected to a reference body length of $11 \mathrm{~cm}$, and the time to $50 \%$ fatigue ( $\pm 1 \mathrm{SE}$ ) was calculated using 10 fish from each treatment by linear regression analysis in $\operatorname{SPSS}^{\circledR}$ (Chicago, IL, USA) of probit fatigue versus log time. Fish were returned to their holding tanks following swim testing.

$\mathrm{Ca}^{2+}$ influx. Unidirectional $\mathrm{Ca}^{2+}$ uptake into trout was determined by exposing fish (eight fish from each treatment) for $4 \mathrm{~h}$, after the $30-\mathrm{d} \mathrm{Cd}$ exposure to radioactive ${ }^{45} \mathrm{Ca}$, according to the method described by Hogstrand et al. [31].

Acclimation. A 96-h LC50 trial was run after the 30-d exposure to assess possible acclimation of metal-exposed fish. Each test cell consisted of eight fish placed randomly into 15L polypropylene buckets having aeration and flowthrough (200 $\mathrm{ml} / \mathrm{min}$ ) of dechlorinated Hamilton tap water at the appropriate $\mathrm{Ca}$ and $\mathrm{Cd}$ level, as added by a mariotte bottle. A total of 48 fish (eight fish for each of the six LC50 test concentrations) were taken from the background and low $\mathrm{Ca}$ treatments and were exposed for $96 \mathrm{~h}$ to $\mathrm{Cd}$ concentrations of $0.07 \pm 0.03$, $0.28 \pm 0.05,0.95 \pm 0.17,3.28 \pm 0.30,14.58 \pm 3.35$, or 16.95 
$\pm 2.85 \mu \mathrm{g} \mathrm{Cd} / \mathrm{L}$ with the appropriate $\mathrm{Ca}$ concentration $(250$ or $470 \mu \mathrm{M})$; the number of water samples $(n)$ for each $\mathrm{Cd}$ concentration was four. Similarly, a total of 48 fish (eight fish per LC50 test concentration) from the medium and high $\mathrm{Ca}$ treatments were exposed for $96 \mathrm{~h}$ to Cd concentrations of 0.20 $\pm 0.05,4.78 \pm 1.69,15.60 \pm 0.30,41.80 \pm 4.82,139.39 \pm$ 27.45 , or $247.77 \pm 61.76 \mu \mathrm{g} \mathrm{Cd} / \mathrm{L}$ with the appropriate $\mathrm{Ca}$ concentration ( 770 or $1200 \mu \mathrm{M})$; again, the number of samples for each $\mathrm{Cd}$ concentration was four. Dead fish were removed when movement ceased, and times of mortality were recorded. The LC50 values ( $\pm 95 \%$ confidence limits) were determined by log probit analysis [32].

Acute and longer-term gill Cd binding. In a previous report [20], we showed that use of radiolabeled ${ }^{109} \mathrm{Cd}$ is essential to distinguish new gill Cd uptake relative to the high background cold concentrations already present in the gills of chronically exposed fish. Acute gill metal uptake/turnover of Cd was determined by exposing the fish for $3 \mathrm{~h}$, after the 30-d Cd exposure, to various concentrations of $\mathrm{Cd}$ labeled with the radioisotope ${ }^{109} \mathrm{Cd}$. Fish were not fed on the day of the gillbinding experiments. A total of 25 fish (five per test concentration) from each of seven treatments (the low $+\mathrm{Cd}$ treatment was excluded due to the low number of surviving fish available) were placed into 35 clear bags containing $10 \mathrm{~L}$ of aerated, soft water $(260 \mu \mathrm{M} \mathrm{Ca})$, which were then placed in a water bath to maintain temperature $\left(13^{\circ} \mathrm{C}\right)$. Each treatment group was exposed to the appropriate acclimation $\mathrm{Ca}$ concentration (260, 470,770 , or $1200 \mu \mathrm{M} \mathrm{Ca}$, added as $\left.\mathrm{Ca}\left[\mathrm{NO}_{3}\right]_{2} \cdot 4 \mathrm{H}_{2} 0\right)$ plus $6 \pm$ $1 \mu \mathrm{g} \mathrm{Cd} / \mathrm{L}, 14 \pm 1 \mu \mathrm{g} \mathrm{Cd} / \mathrm{L}, 27 \pm 1 \mu \mathrm{g} \mathrm{Cd} / \mathrm{L}, 63 \pm 2 \mu \mathrm{g}$ $\mathrm{Cd} / \mathrm{L}$, or $115 \pm 2 \mu \mathrm{g} \mathrm{Cd} / \mathrm{L}$. The number of samples for each $\mathrm{Cd}$ concentration was 14 , and $\mathrm{Cd}$ was added as $\mathrm{Cd}\left(\mathrm{NO}_{3}\right)_{2} \cdot 4 \mathrm{H}_{2} \mathrm{O}$, with $1 \mu \mathrm{Ci} / \mathrm{L}$ of ${ }^{109} \mathrm{Cd}$ added as $\mathrm{CdCl}_{2}$ (specific activity $=1.97$ $\mathrm{mCi} / \mathrm{mg}$ ). Water samples $(5 \mathrm{ml})$ were taken at the beginning and end of the 3-h static exposure. Gills were sampled at $3 \mathrm{~h}$. Gills were removed, rinsed, acid digested, and later analyzed for total $\mathrm{Cd}$ and ${ }^{109} \mathrm{Cd}$ radioactivity (see the discussion of tissue analyses).

A longer-term gill $\mathrm{Cd}$ uptake/turnover experiment was run after the 30-day $\mathrm{Cd}$ exposure by exposing the fish for $72 \mathrm{~h}$ to the $\mathrm{Cd}$ radioisotope ${ }^{109} \mathrm{Cd}$ at a total $\mathrm{Cd}$ concentration approximately threefold higher than the nominal chronic exposure concentration. Twenty fish from each treatment (or fewer, depending on availability) were placed into 10 clear bags containing $15 \mathrm{~L}$ of aerated, soft water $(260 \mu \mathrm{M} \mathrm{Ca})$, which were then placed in a water bath to maintain temperature $\left(13^{\circ} \mathrm{C}\right)$. Each treatment group was exposed to the appropriate $\mathrm{Ca}$ concentration $(260,470,770$, or $1200 \mu \mathrm{M} \mathrm{Ca}$, added as $\left.\mathrm{Ca}\left[\mathrm{NO}_{3}\right]_{2} \cdot 4 \mathrm{H}_{2} \mathrm{O}\right)$ plus $6 \pm 1 \mu \mathrm{g} \mathrm{Cd} / \mathrm{L}(n=5)$, with the $\mathrm{Cd}$ added as $\mathrm{Cd}\left(\mathrm{NO}_{3}\right)_{2} \cdot 4 \mathrm{H}_{2} \mathrm{O}$, and $1 \mu \mathrm{Ci} / \mathrm{L}{ }^{109} \mathrm{Cd}$ added as $\mathrm{CdCl}_{2}$ (specific activity $=1.97 \mathrm{mCi} / \mathrm{mg}$ ). Water samples $(5 \mathrm{ml})$ were taken daily during the $72-\mathrm{h}$ static exposure. Gills of five fish were sampled at $12,24,48$, and $72 \mathrm{~h}$. Gills were removed, rinsed, digested in $1 \mathrm{~N} \mathrm{HNO}_{3}$, and later analyzed for total $\mathrm{Cd}$ and radioactivity from ${ }^{109} \mathrm{Cd}$ (see the discussion of tissue analyses).

\section{Chemical analyses}

Tissue analyses. The concentrations of all measured parameters in tissues were expressed on a per gram wet tissue basis.

Gills, livers, kidneys, and remaining carcass were thawed, weighed, and then digested in one- to 15 -fold their weight of $1 \mathrm{~N} \mathrm{HNO}_{3}$ (TraceMetal Grade $\mathrm{HNO}_{3}$, Fisher Scientific, Nepean, ON, Canada) for $15 \mathrm{~h}$ at approximately $60^{\circ} \mathrm{C}$. Digests were shaken, left to settle for $10 \mathrm{~min}$, and the supernatant then diluted 20- to 200-fold with deionized water, as appropriate (18 mgohm; Nanopure II, Sybron/Barnstead, Boston, MA, USA). Gill, liver, kidney, and carcass Cd concentrations were measured on a graphite furnace atomic absorption spectrophotometer (Varian AA-1275 with GTA-95 atomizer, Varian Techtron, Springvale, CA, USA) against Fisher certified standards, as outlined by Hollis et al. [33], using 10- $\mu$ l injection volumes and $\mathrm{N}_{2}$ gas. Operating conditions were as those described by Varian, with $30 \mathrm{~s}$ of drying time at $90^{\circ} \mathrm{C}, 12 \mathrm{~s}$ at $120^{\circ} \mathrm{C}$, and $4 \mathrm{~s}$ at $1800^{\circ} \mathrm{C}$, during which $\mathrm{Cd}$ was analyzed. The matrices for standards were the same as for unknowns, and samples were always read above the lowest standard on the calibration curve. Reproducibility on duplicate analyses was typically $\pm 10 \%$.

Whole-body Cd was calculated based on the data for individual fish at each sample time using the following equation:

$W B=[(G \times g w t)+(L \times l w t)+(K \times k w t)+(C \times c w t)] / f w t$

where $W B$ is whole-body Cd accumulation ( $\mu \mathrm{g} \mathrm{Cd} / \mathrm{g}$ wet tissue), $G$ is gill $\mathrm{Cd}$ accumulation ( $\mu \mathrm{g} \mathrm{Cd} / \mathrm{g}$ wet tissue), $L$ is liver $\mathrm{Cd}$ accumulation ( $\mu \mathrm{g} \mathrm{Cd} / \mathrm{g}$ wet tissue), $K$ is kidney $\mathrm{Cd}$ accumulation ( $\mu \mathrm{g} \mathrm{Cd} / \mathrm{g}$ wet tissue), $C$ is carcass $\mathrm{Cd}$ accumulation ( $\mu \mathrm{g} \mathrm{Cd} / \mathrm{g}$ wet tissue), gwt is the weight of the gills (g), lwt is the weight of the liver $(\mathrm{g}), k w t$ is the weight of the kidney $(\mathrm{g})$, $c w t$ is the weight of the carcass (g), and fwt is the weight of the fish (g). Gills, liver, kidney, and carcass represent $3.0 \%$, $1.5 \%, 0.5 \%$, and $95.0 \%$ of the total whole-body weight, respectively. Levels of $\mathrm{Ca}$ and $\mathrm{Na}$ in the carcass were measured by atomic absorption spectrophotometry using the dilutions from the acid digests and methods as used for the water and plasma samples (discussed later).

The frozen fish from the $\mathrm{Ca}$ influx experiment were transferred to liquid nitrogen and ground to a fine powder with a tissue grinder (Janke and Kunkel GMBH, IKA-Laboratories, Markham, ON, Canada). The powder was weighed out in triplicate samples of $0.5 \mathrm{~g}$ in glass scintillation vials. Each tissue sample was digested with $2.0 \mathrm{ml}$ of liquid tissue solubilizer (Soluene-350, Canberra-Packard, Mississauga, ON, Canada) for $48 \mathrm{~h}$ at $45^{\circ} \mathrm{C}$. The samples were then diluted with $10 \mathrm{ml}$ of scintillation fluor (Hionic Fluor, Canberra-Packard) and counted in a scintillation counter (1217 Rackbeta Liquid Scintillation Counter, LKB-Wallac, Turku, Finland) with quench correction by internal standardization. The inward flux $\left(J_{\text {in }}\right)$ for $\mathrm{Ca}^{2+}$ (in $\mu \mathrm{M} / \mathrm{kg} / \mathrm{h}$ ) was calculated according to the formula described by Hogstrand et al. [31].

Tissue ${ }^{109} \mathrm{Cd}$ concentrations were measured on a Minaxi Auto-Gamma 5000 Series Gamma Counter (Canberra Packard Instrument, Meriden, CT, USA). Tissue ${ }^{109} \mathrm{Cd}$ concentrations were converted to absolute values (new $\mathrm{Cd}$ ) using the measured specific activity $(b / c)$ of the water:

\section{$a /(b / c)$}

where $a$ is ${ }^{109} \mathrm{Cd}$ cpm per gram of tissue (wet weight), $b$ is ${ }^{109} \mathrm{Cd}$ counts in the water $(\mathrm{cpm} / \mathrm{L})$, and $c$ is the total $\mathrm{Cd}$ concentration in the water $(\mu \mathrm{g} \mathrm{Cd} / \mathrm{L})$.

Gill Cd dissociation constants and capacity were calculated using Scatchard analysis as outlined by Reid and McDonald [34]. The amount of Cd bound by the gill was divided by the free ionic $\mathrm{Cd}^{2+}$ concentration in the water and plotted against the amount of $\mathrm{Cd}$ bound by the gill. The $K_{\mathrm{D}}$ and the total $B_{\max }$ of the gill were then determined from the slope and $x$-intercept of the Scatchard plot, respectively. All plots were linear, with 
$r$ values ranging from 0.71 to 0.99 . Concentrations of $\mathrm{Cd}^{2+}$ and other $\mathrm{Cd}$ species in the water were calculated using the MINEQL+ aquatic geochemical program [35] and measured water chemistry.

Water and plasma analyses. Water and plasma $\mathrm{Na}$ and $\mathrm{Ca}$ concentrations were measured using the Varian AA-1275 operated in standard flame absorption mode. Water Cd concentrations were measured using the methods described for tissues. Water and whole-body $\mathrm{Cl}$ concentrations were measured on the acid digests using the colorimetric assay described by Zall et al. [36] and read with an MRX microplate reader (Dynatech Laboratories, Chantilly, VA, USA). Water $\mathrm{pH}$ was measured using a Radiometer PHM71b meter with GK2401C combination electrode (Radiometer, Copenhagen, Denmark). Dissolved organic matter was measured on a Rosemount Analytical DC-180 automated total organic carbon analyzer (Folio Instruments, Kitchener, ON, Canada).

Duplicate water samples from the Ca flux experiment were acidified and analyzed for calcium by atomic absorption spectroscopy (Varian AA-1275) and for Cd by graphite furnace (Varian AA-1275 with GTA-95 atomizer, Varian Techtron). The remaining duplicate water samples ( $5 \mathrm{ml}$ each) were diluted with $10 \mathrm{ml}$ of scintillation fluor (Hionic Fluor) and counted for ${ }^{45} \mathrm{Ca}$.

\section{Statistics}

Data are expressed as means $\pm 1 \mathrm{SE}(n)$, except in the case of LC50 values, in which means $\pm 95 \%$ confidence limits are reported. The LC50 values, specific growth rates, and swimming times were compared by means of the Bonferroni adjustment to the independent two-tailed Student's $t$ test. For all other data, analysis of variance followed by a Student-Newman-Keuls procedure was used for multiple comparisons of mean values. A fiducial limit of $p<0.05$ was used throughout.

\section{RESULTS}

\section{Effects of exposure}

The actual concentrations of $\mathrm{Cd}$ and $\mathrm{Ca}$ measured in the exposure tanks are reported in Table 1 . In the background and low $+\mathrm{Cd}$ exposures, $\mathrm{Cd}$ concentration averaged $55 \%$ greater than nominal, whereas in the medium and high $+\mathrm{Cd}$ exposures, it averaged $20 \%$ less than nominal. Calcium concentrations were within $7 \%$ of nominal in all treatments, except for the medium $\mathrm{Ca}(22 \%$ greater than nominal) and the medium $+\mathrm{Cd}(22 \%$ less than nominal).

Fish mortality during the $30-\mathrm{d}$ exposure was greatest ( $\sim 80 \%$ in total) in the background $+\mathrm{Cd}$ treatment, with acute toxicity ( $\sim 50 \%$ mortality) occurring within the first $5 \mathrm{~d}$ (Table 1). Approximately $40 \%$ mortality was observed in the low + $\mathrm{Cd}$-treated fish during the $30-\mathrm{d}$ exposure, and approximately $10 \%$ mortality was observed in all other treatments (Table 1). Despite the submaximal diet, in no instance was the growth of the surviving fish decreased with $\mathrm{Ca}$ (mean growth rate of Ca-exposed fish $=0.93 \pm 0.20 \% / \mathrm{d}, n=4$ ) and/or Cd exposure (mean growth rate of Cd-exposed fish $=0.87 \pm 0.20 \% / \mathrm{d}, n$ $=4)$.

Cadmium accumulation in all tissues decreased as water Ca concentration increased (Fig. 1). Cadmium concentrations were greatest in kidney (Fig. 1C), followed by gills (Fig. 1A) and liver (Fig. 1B). Gill Cd levels were significantly increased $(p<0.05)$ by 14-, nine-, 12-, and eightfold from the initial (day 0$)$ values $(0.30 \pm 0.02 \mu \mathrm{g} \mathrm{Cd} / \mathrm{g}$ wet tissue, $n=6$ ) for
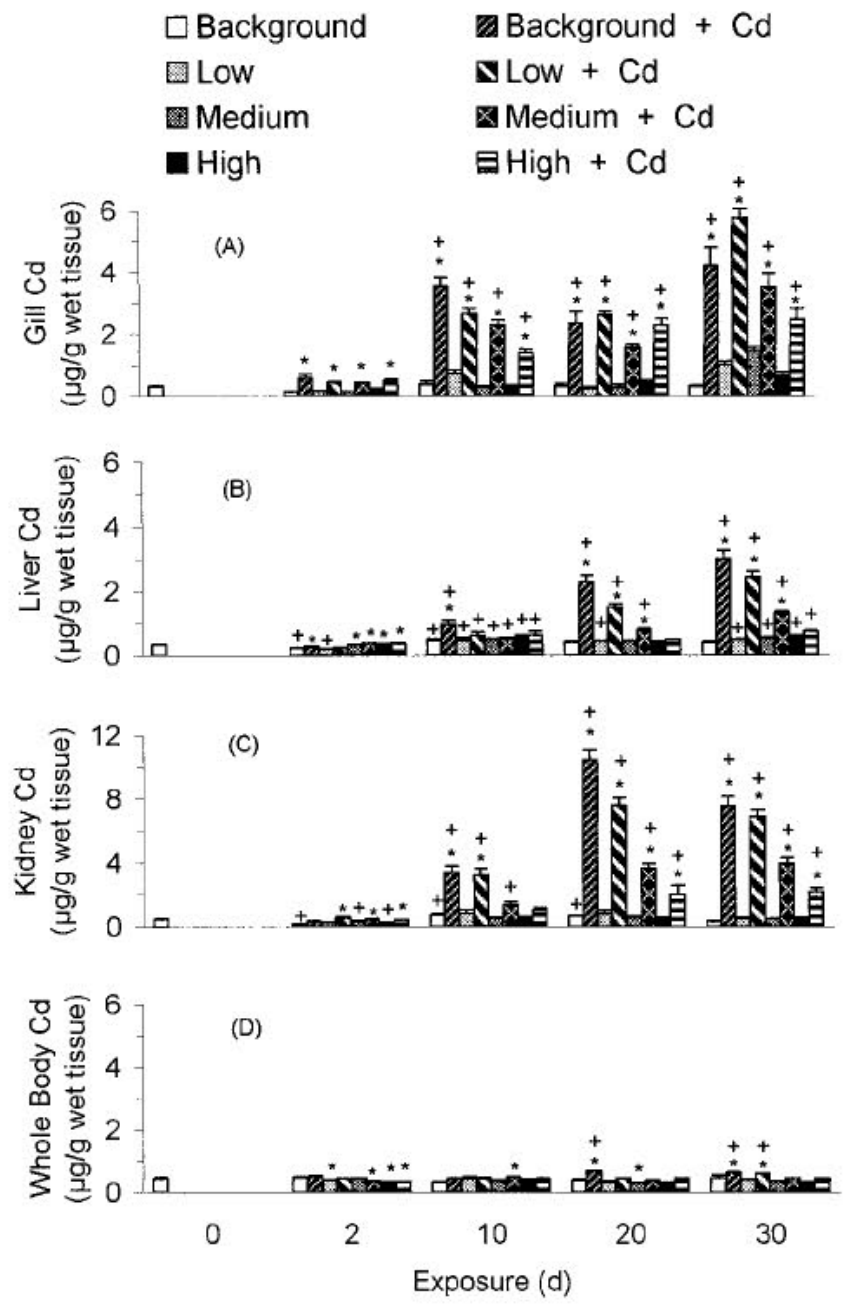

Fig. 1. Accumulation of Cd by gills (A), liver (B), kidney (C), and whole body (D) of juvenile rainbow trout exposed to background, low, medium, or high $\mathrm{Ca}$ with $\mathrm{Cd}$ (patterned bars) or without $\mathrm{Cd}$ (shaded bars) for $30 \mathrm{~d}$. Data are presented as means $\pm 1 \mathrm{SE}(n=6)$. Statistically significant differences $(p<0.05)$ are indicated for $\mathrm{Cd}+$ $\mathrm{Ca}$ exposures against respective $\mathrm{Ca}$ concentrations $(260,470,770$, and $1200 \mu \mathrm{M})$ at each sampling day $\left({ }^{*}\right)$ and against background $\mathrm{Ca}$ at day $0(+)$.

$\mathrm{Cd}+$ background, low, medium, and high $\mathrm{Ca}$ exposures, respectively, after $30 \mathrm{~d}$ of exposure (Fig. 1A). Liver Cd concentrations were significantly increased by nine-, seven-, four-, and twofold from the initial values $(0.34 \pm 0.03 \mu \mathrm{g} \mathrm{Cd} / \mathrm{g}$ wet tissue, $n=6$ ) for $\mathrm{Cd}+$ background, low, medium, and high Ca exposures, respectively (Fig. 1B).

Kidney Cd levels were significantly increased by 16-, 15-, eight-, and fivefold from the initial values $(0.47 \pm 0.02 \mu \mathrm{g}$ $\mathrm{Cd} / \mathrm{g}$ wet tissue, $n=6$ ) for $\mathrm{Cd}+$ background, low, medium, and high Ca exposures, respectively (Fig. 1C). Remaining carcass $\mathrm{Cd}$ levels were not significantly different $(p>0.05)$ from the initial values for any of the treatments, and average carcass $\mathrm{Cd}$ concentrations were $0.38 \pm 0.03 \mu \mathrm{g} \mathrm{Cd} / \mathrm{g}$ wet tissue (data not shown, $n=33$ ). Whole-body Cd concentrations were significantly increased $(p<0.05)$ by 1.5 - and 1.4 -fold from the initial values of $0.43 \pm 0.04 \mu \mathrm{g} \mathrm{Cd} / \mathrm{g}$ wet tissue $(n=6)$ for background $+\mathrm{Cd}$ and low $+\mathrm{Cd}$, respectively (Fig. 1D). The exposures of medium $+\mathrm{Cd}$ and high $+\mathrm{Cd}$ were not significantly different $(p>0.05)$ from the initial whole-body $\mathrm{Cd}$ values (Fig. 1D). 

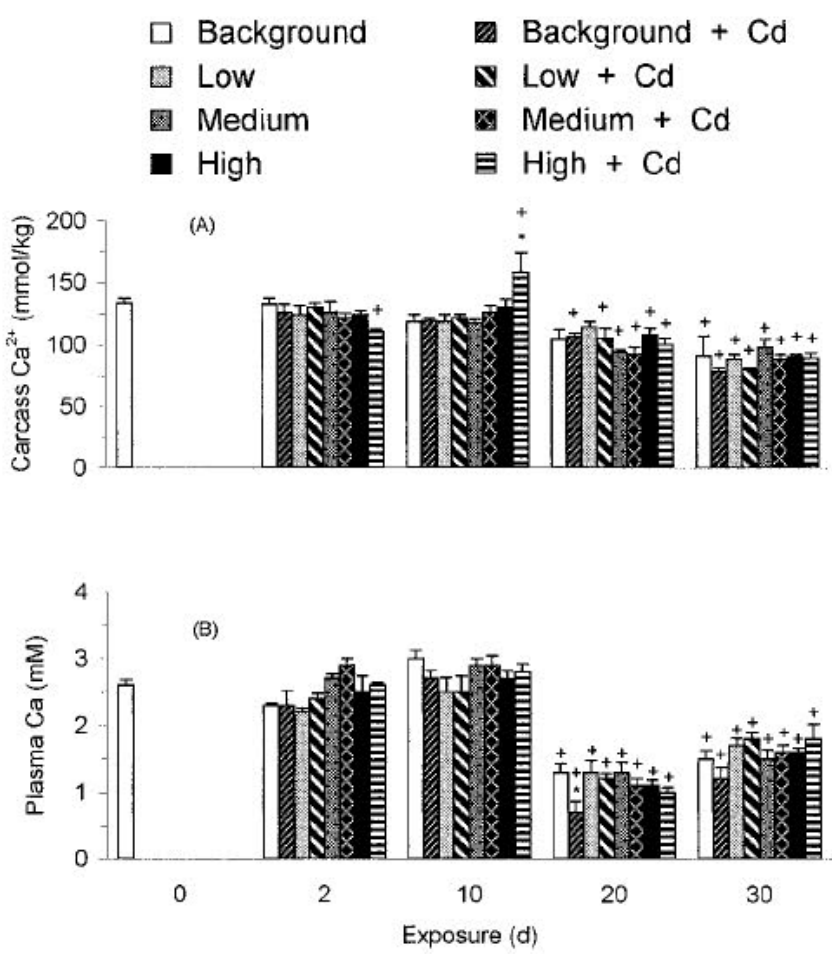

Fig. 2. Carcass (A) and plasma $\mathrm{Ca}$ (B) concentrations of juvenile rainbow trout exposed to background, low, medium, or high $\mathrm{Ca}$ with $\mathrm{Cd}$ (patterned bars) or without $\mathrm{Cd}$ (shaded bars). Error bars represent $\pm 1 \mathrm{SE}(n=6)$. Statistically significant differences $(p<0.05)$ are indicated for $\mathrm{Cd}+\mathrm{Ca}$ exposures against respective $\mathrm{Ca}$ concentrations $(260,470,770$, and $1200 \mu \mathrm{M})$ at each sampling day $\left({ }^{*}\right)$ and against background $\mathrm{Ca}$ at day $0(+)$.

\section{Acclimation}

These small-scale toxicity tests suggested that toxicological acclimation to $\mathrm{Cd}$ only occurred for the background and low $+\mathrm{Cd}$-treated fish. Ninety-six-hour LC50 values were $2.53 \pm$ $1.91,2.35 \pm 1.16,2.15 \pm 2.50$, and $1.15 \pm 0.58 \mu \mathrm{g} \mathrm{Cd} / \mathrm{L}$ for background, low, medium, and high Ca treatments, respectively. By way of comparison, the corresponding 96-h LC50 values for the $\mathrm{Cd}$-exposed fish were greater than 24.33 , greater than $17.00,1.90 \pm 1.88$, and $6.90 \pm 6.84 \mu \mathrm{g} \mathrm{Cd} / \mathrm{L}$, respectively. The fish exposed to $\mathrm{Cd}+$ background or low Ca showed a trend of increased tolerance to $\mathrm{Cd}$; however, because less than $50 \%$ mortality occurred in the highest concentration tested, 96-h LC50 values could not be calculated for these two groups.

\section{Physiological effects and costs of chronic exposure}

No consistent treatment or time-related effects were seen in carcass and plasma $\mathrm{Ca}$, which averaged $111 \pm 5 \mathrm{mmol} / \mathrm{kg}$ $(n=198)$ and $2.0 \pm 0.1 \mathrm{mM}(n=198)$, respectively (Fig. 2). Carcass $\mathrm{Na}^{+}$and $\mathrm{Cl}^{-}$concentrations averaged $37 \pm 5 \mathrm{mmol} /$ $\mathrm{kg}(n=198)$ and $40 \pm 3 \mathrm{mmol} / \mathrm{kg}(n=198)$, respectively, also with no consistent treatment or time effects.

Swimming stamina was not significantly altered by exposure to different water $\mathrm{Ca}$ concentrations in the absence of $\mathrm{Cd}$. However, in the presence of chronic Cd exposure (30 d), a tendency for swimming impairment at low water $\mathrm{Ca}$ concentrations was seen (Fig. 3). Swimming performance, as determined by time to $50 \%$ fatigue, was significantly decreased ( $p$ $<0.05$ ) with chronic exposure to low $+\mathrm{Cd}$ (Fig. 3).

Unidirectional influx of $\mathrm{Ca}$, as assessed by ${ }^{45} \mathrm{Ca}$ appearance $\square$ No Cd added $\mathbf{Z}$ Cd-exposed

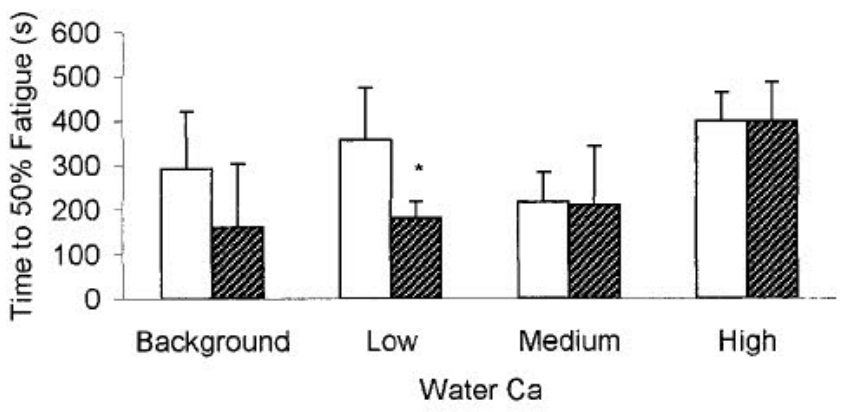

Fig. 3. Swimming performance (stamina) of juvenile rainbow trout after 30 days exposure to background, low, medium, or high $\mathrm{Ca}$ with $\mathrm{Cd}$ (striped bars) or without Cd (clear bars). Swimming times were corrected to a reference length of $11 \mathrm{~cm}$ (average length of fish tested [30]). Data are presented as means $\pm 1 \mathrm{SE}(n=10)$. Statistical comparisons were made for $\mathrm{Cd}+\mathrm{Ca}$ exposures against respective Ca concentrations $(260,470,770$, and $1200 \mu \mathrm{M}) .{ }^{*}=p<0.05$.

in whole bodies, decreased significantly $(p<0.05)$ compared with background $\mathrm{Ca}$ at medium and high water $\mathrm{Ca}$ concentrations in the absence of $\mathrm{Cd}$ (Fig. 4). Unidirectional $\mathrm{Ca}$ influx was decreased by $50 \%$ with chronic exposure to $\mathrm{Cd}$ at background water $\mathrm{Ca}$ compared with controls, but it was not affected at higher water $\mathrm{Ca}$ levels.

\section{Cadmium uptake/turnover in gills of acclimated trout}

In all groups of the acute (3-h) Cd uptake/turnover test, uptake increased with increasing acute exposure concentrations of radiolabeled $\mathrm{Cd}$, with uptake tending toward saturation at higher concentrations (Fig. 5). Fish in the background $\mathrm{Ca}$ treatment reached approximate saturation when exposed to 115 $\mu \mathrm{g} \mathrm{Cd} / \mathrm{L}$ for $3 \mathrm{~h}$, with approximately $1.15 \mu \mathrm{g} / \mathrm{g}$ of new waterborne $\mathrm{Cd}$ bound to the gills (Fig. 5A). With increased water $\mathrm{Ca}$ concentrations, uptake of new $\mathrm{Cd}$ by gills decreased. Trout that had been exposed to low, medium, and high water $\mathrm{Ca}$ concentrations for $30 \mathrm{~d}$ had $37 \%, 50 \%$, and $64 \%$ decreases in new gill $\mathrm{Cd}$ uptake, respectively, compared with controls at the highest $\mathrm{Cd}$ concentration tested $(115 \mu \mathrm{g} / \mathrm{L} ; p<0.05$; Fig. $5 \mathrm{~A})$. Similar trends with increasing water $\mathrm{Ca}$ levels $(470,770$, and $1200 \mu \mathrm{M}$ ) were seen in fish that had been exposed to $\mathrm{Cd}$ for $30 \mathrm{~d}$ (Fig. 5B).

At each $\mathrm{Ca}$ concentration, new $\mathrm{Cd}$ accumulation in the gills

\section{$\square$ No Cd added $凤$ Cd-exposed}

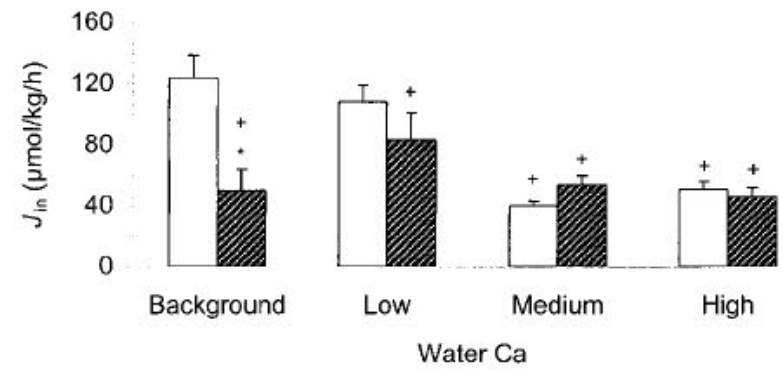

Fig. 4. Unidirectional influx of $\mathrm{Ca}$, as measured with ${ }^{45} \mathrm{Ca}$, into juvenile rainbow trout after 30-d exposure to background, low, medium, or high $\mathrm{Ca}$ with $\mathrm{Cd}$ (striped bars) or without $\mathrm{Cd}$ (controls; clear bars). Error bars represent $\pm 1 \mathrm{SE}(n=8)$. Statistically significant differences $(p<0.05)$ are indicated for $\mathrm{Cd}+\mathrm{Ca}$ exposures against respective Ca concentrations $\left(260,470,770\right.$, and $\left.1200 \mu \mathrm{M} ;{ }^{*}\right)$ and against background $\mathrm{Ca}(+)$. 

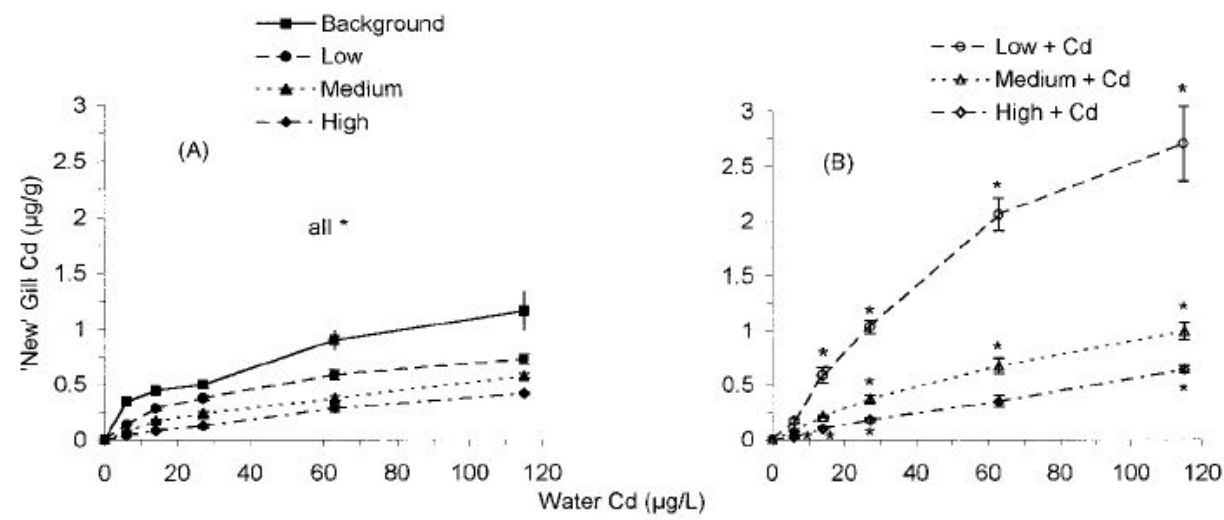

Fig. 5. Accumulation of new $\mathrm{Cd}$ by gills of Ca-exposed (A) and $\mathrm{Cd}+\mathrm{Ca}$ (background [squares], low [circles], medium [triangles], and high [diamonds]-exposed trout $(B)$ acutely exposed $(3 \mathrm{~h})$ to ${ }^{109} \mathrm{Cd}$ with total $\mathrm{Cd}$ concentrations of $6,14,27,63$, and $115 \mu \mathrm{g} / \mathrm{L}$. Data are presented as means $\pm 1 \mathrm{SE}(n=5)$. Statistical comparisons were made against background $\mathrm{Ca}$ exposure at each sampling concentration for $\mathbf{A}$ and against respective $\mathrm{Ca}$ concentration from $\mathbf{A}$ at each sampling concentration for $\mathbf{B} .{ }^{*}=p<0.05$.

increased significantly $(p<0.05)$ with chronic Cd exposure (Fig. 5B). At the highest test concentration $(115 \mu \mathrm{g} \mathrm{Cd} / \mathrm{L})$, uptake of new $\mathrm{Cd}$ by gills increased 3.8-, 1.7-, and 1.6-fold for the low $+\mathrm{Cd}$, medium $+\mathrm{Cd}$, and high $+\mathrm{Cd}$ groups, respectively (Fig. 5B), compared with their respective control groups at the same Ca levels $(470,770$, or $1200 \mu \mathrm{M})$ without Cd (Fig. 5A).

Cadmium speciation analyses from MINEQL+ [35] indicated that 60 to $94 \%$ of the total Cd existed as the free ionic species $\mathrm{Cd}^{2+}$ for exposures ranging from 6 to $115 \mu \mathrm{g} / \mathrm{L}$, respectively. Calcium concentrations of the test waters (background, low, medium, and high $\mathrm{Ca}$ ) did not affect $\mathrm{Cd}^{2+}$ speciation to a large extent. A less than $1 \%$ decrease in free ionic $\mathrm{Cd}^{2+}$ concentration was found as water $\mathrm{Ca}$ levels increased from background to high (from $54.9 \%$ to $54.7 \%$ of total $\mathrm{Cd}$ as $\mathrm{Cd}^{2+}$ for background and high $\mathrm{Ca}$, respectively, with the remainder bound to DOM). Scatchard analysis of Cd uptake/ turnover for the 3-h exposure to radioactive ${ }^{109} \mathrm{Cd}$ (Fig. 5A) was done using ionic $\mathrm{Ca}^{2+}$. This analysis indicated a trend for decreasing conditional stability constants ( $\log K_{\mathrm{Cd} \text {-gill }}$; decreasing affinity) and for decreasing $B_{\max }$ values (number of gill Cd-binding sites) for Ca-exposed fish as the chronic $\mathrm{Ca}$ exposure level increased (Table 2). Furthermore, at each calcium concentration, conditional stability constants decreased with chronic exposure to cadmium. The number of gill Cd-binding sites ( $B_{\max }$ values) tended to increase with chronic Cd exposure, particularly for the low $+\mathrm{Cd}$-treated fish (Table 2).

The data set for the longer-term gill-binding exposure (72 h) is incomplete due to mortality during the 72-h exposure (Fig. 6) as well as mortality during the 30 -d chronic exposure to cadmium (Table 1), which limited the number of fish that

Table 2. $\log K_{\text {Cd-gill }}$ (conditional stability constants) and $B_{\max }$ (number of gill $\mathrm{Cd}$ binding sites) of juvenile rainbow trout, calculated against ionic $\mathrm{Cd}^{2+}$, after $30 \mathrm{~d}$ of exposure to background, low, medium, or high $\mathrm{Ca}$ or without $\mathrm{Cd}$

\begin{tabular}{lccccc} 
& \multicolumn{2}{c}{ No Cd added } & & \multicolumn{2}{c}{$2 \mu \mathrm{g} / \mathrm{L}$ Cd added } \\
\cline { 2 - 3 } \cline { 5 - 6 } Ca concentration & $\log K_{\text {Cd-gill }}$ & $\begin{array}{c}B_{\max } \\
(\mu \mathrm{mol} / \mathrm{g})\end{array}$ & & $\log K_{\text {Cd-gill }}$ & $\begin{array}{c}B_{\max } \\
(\mu \mathrm{mol} / \mathrm{g})\end{array}$ \\
\hline Background & 7.0 & 0.010 & & - & - \\
Low & 6.9 & 0.007 & & 6.2 & 0.042 \\
Medium & 6.6 & 0.006 & & 6.3 & 0.012 \\
High & 6.3 & 0.005 & & 5.8 & 0.015 \\
\hline
\end{tabular}

could be tested. The longer-term gill-binding exposure to 6 $\mu \mathrm{g} \mathrm{Cd} / \mathrm{L}$ for $72 \mathrm{~h}$ again revealed pronounced influences of both the water $\mathrm{Ca}$ concentration and the effects of chronic $\mathrm{Cd}$ exposure. Gill uptake of new $\mathrm{Cd}$ decreased as water $\mathrm{Ca}$ increased, but gill accumulation of new $\mathrm{Cd}$ increased with chronic exposure to $2 \mu \mathrm{g} \mathrm{Cd} / \mathrm{L}$ (Fig. 6). The total Cd concentrations in gills remained constant during the 72-h exposure (data not shown).

\section{DISCUSSION}

\section{Environmental relevance}

The U.S. Environmental Protection Agency (U.S. EPA) freshwater-quality criteria for aquatic life regarding water hardness ranging from $20 \mathrm{mg} / \mathrm{L}$ as $\mathrm{CaCO}_{3}$ (close to our low $\mathrm{Ca}$ exposure) to $120 \mathrm{mg} / \mathrm{L}$ as $\mathrm{CaCO}_{3}$ (close to our high $\mathrm{Ca}$ exposure) recommend an acute limit of 0.6 to $4.8 \mu \mathrm{g} \mathrm{Cd} / \mathrm{L}$, respectively, for acute $\mathrm{Cd}$ exposures [23]. Limits set by the U.S. EPA for chronic Cd exposures are 0.3 and $1.3 \mu \mathrm{g} \mathrm{Cd} / \mathrm{L}$ for water hardness, ranging from 20 to $120 \mathrm{mg} / \mathrm{L}$ as $\mathrm{CaCO}_{3}$, respectively [23]. Note, however, that U.S. EPA criteria may not be implemented at low hardness, because the hardness relationship is thought to be incompletely characterized at less than $50 \mathrm{mg} / \mathrm{L}$. We used a nominal Cd concentration of $2.0 \mu \mathrm{g} /$ $\mathrm{L}$ for our experiment, which is also relevant to Canadian waterquality guidelines of 0.2 and $1.3 \mu \mathrm{g} \mathrm{Cd} / \mathrm{L}$ for protection of freshwater life exposed chronically to cadmium in soft and hard water, respectively [24].

\section{Costs of Cd exposure}

Despite the restricted ration, no significant effects on growth were observed during the $30-\mathrm{d}$ exposure to $\mathrm{Cd}$ plus increasing water $\mathrm{Ca}$ concentrations. Therefore, growth was not a sensitive indicator of ongoing sublethal $\mathrm{Cd}$ exposure. Other reports on chronic $\mathrm{Cd}$ exposure, many run at higher ration levels, support these findings of no adverse effects on growth $[6,20,37,38]$.

Whole-body and plasma Ca concentrations were not consistently changed with chronic $\mathrm{Cd}$ exposure and increasing water $\mathrm{Ca}$ concentrations (Fig. 2). Hollis et al. [20] also found no significant differences in whole-body ions with chronic $\mathrm{Cd}$ exposures in hard water $\left(140 \mathrm{mg} / \mathrm{L}\right.$ as $\left.\mathrm{CaCO}_{3}\right)$. Giles [15] showed that plasma calcium and magnesium concentrations were not significantly changed at exposures of $3.6 \mu \mathrm{g} \mathrm{Cd} / \mathrm{L}$ at a water hardness of $82 \mathrm{mg} / \mathrm{L}$ as $\mathrm{CaCO}_{3}$, but that they were 

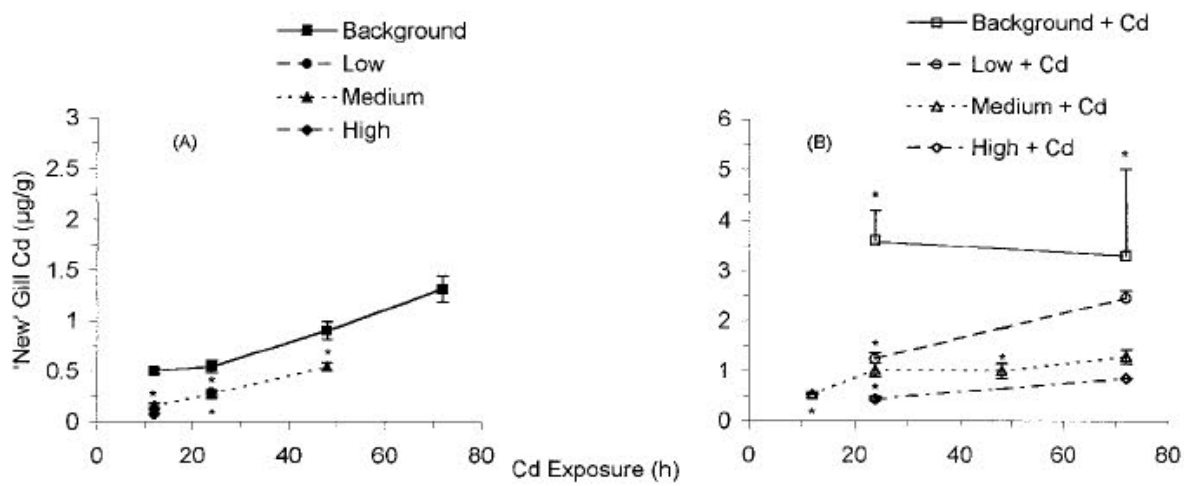

Fig. 6. Accumulation of new $\mathrm{Cd}$ by gills of rainbow trout exposed for $72 \mathrm{~h}$ to ${ }^{109} \mathrm{Cd}$, with total $\mathrm{Cd}$ concentration of $6 \mu \mathrm{g} / \mathrm{L}$, after $30-\mathrm{d}$ exposures to background (squares), low (circles), medium (triangles), or high (diamonds) Ca without Cd (A) or with Cd (B). Data are presented as means $\pm 1 \mathrm{SE}(n=1-5)$. Statistical comparisons were made against background $\mathrm{Ca}$ exposure at each sampling concentration for $\mathbf{A}$ and against the respective $\mathrm{Ca}$ concentration from $\mathbf{A}$ at each sampling concentration for $\mathbf{B}$. Note the scale difference in $\mathbf{B}$. ${ }^{*}=p<0.05$.

decreased at $6.4 \mu \mathrm{g} \mathrm{Cd} / \mathrm{L}$ exposures. Reid and $\mathrm{McD}$ Donald [39] demonstrated no adverse effects from $6.5 \mu \mathrm{g} \mathrm{Cd} / \mathrm{L}$ on plasma $\mathrm{Ca}$ and $\mathrm{Na}$ levels during a 24-h exposure in both hard $(\mathrm{Ca}=$ $1 \mathrm{mM})$ and soft $(\mathrm{Ca}=0.04 \mathrm{mM})$ water; however, whole-body influx of $\mathrm{Ca}^{2+}$ from the water was significantly reduced.

In contrast, swimming performance responded to $\mathrm{Cd}$ exposure at the lower $\mathrm{Ca}$ concentrations. Sprint performance was significantly reduced for the low $+\mathrm{Cd}$-exposed fish (Fig. 3). Scherer et al. [40] reported impaired swimming performance, as represented by foraging ability of adult lake trout exposed to $0.5 \mu \mathrm{g} \mathrm{Cd} / \mathrm{L}$ at a water hardness of $90 \mathrm{mg} / \mathrm{L}$ as $\mathrm{CaCO}_{3}$; however, escape of the prey (rainbow trout fingerlings) from the lake trout was not impaired by the $\mathrm{Cd}$ exposure.

The primary mechanism of acute $\mathrm{Cd}$ toxicity is fatal hypocalcemia resulting from irreversible blockage of $\mathrm{Ca}^{2+}$ uptake across the gills, apparently by noncompetitive inhibition of an essential transport enzyme, high-affinity $\mathrm{Ca}^{2+}$ ATPase [41,42]. Uptake of $\mathrm{Ca}^{2+}$ did not recover within a 12-h period once the $\mathrm{Cd}$ (a high level of $730 \mu \mathrm{g} \mathrm{Cd} / \mathrm{L}$ ) was removed, suggesting that $\mathrm{Cd}$ causes permanent damage to the $\mathrm{Ca}^{2+}$ ATPase [39]. In the present study, unidirectional influx of $\mathrm{Ca}^{2+}$ into trout was significantly reduced with chronic $\mathrm{Cd}$ exposure at the background $\mathrm{Ca}$ concentration (Fig. 4). Unidirectional influx of $\mathrm{Ca}^{2+}$ into trout was also significantly reduced at the medium and high water $\mathrm{Ca}$ concentrations, with or without $\mathrm{Cd}$ (Fig. 4), whereas whole-body and plasma $\mathrm{Ca}^{2+}$ concentrations were not significantly different at the various water $\mathrm{Ca}$ concentrations (Fig. 2). Reid and McDonald [39] reported similar results with significant inhibition of $\mathrm{Ca}^{2+}$ influx in rainbow trout exposed for $24 \mathrm{~h}$ to $6.5 \mu \mathrm{g} \mathrm{Cd} / \mathrm{L}$. In addition, the degree of inhibition of $\mathrm{Ca}^{2+}$ influx due to $\mathrm{Cd}$ exposure relative to control fish was greater in soft water-acclimated $\left(\mathrm{Ca}^{2+}=0.04 \mathrm{mM}\right)$ than hard water-acclimated $\left(\mathrm{Ca}^{2+}=1 \mathrm{mM}\right)$ trout [39].

Because both water $\mathrm{Ca}$ and $\mathrm{Cd}$ effects on unidirectional $\mathrm{Ca}^{2+}$ influx occurred in the present study without effects on whole-body $\mathrm{Ca}^{2+}$ concentrations or growth, compensating changes in $\mathrm{Ca}^{2+}$ efflux are likely to have occurred. Verbost et al. [42] demonstrated that transepithelial $\mathrm{Ca}^{2+}$ efflux in the gills of rainbow trout is less sensitive than the $\mathrm{Ca}^{2+}$ influx to $\mathrm{Cd}^{2+}$. Efflux of $\mathrm{Ca}^{2+}$ did not occur in the gills of trout exposed to $0.1 \mu \mathrm{M} \mathrm{Cd}(11 \mu \mathrm{g} \mathrm{Cd} / \mathrm{L})$; however, $\mathrm{Ca}^{2+}$ efflux was significantly stimulated at a Cd concentration of $1 \mu \mathrm{M}(112 \mu \mathrm{g}$ $\mathrm{Cd} / \mathrm{L})$. In contrast, Reid and McDonald [39] found no significant effects on $\mathrm{Ca}^{2+}$ efflux in whole bodies of rainbow trout during a 24-h exposure to $6.5 \mu \mathrm{g} \mathrm{Cd} / \mathrm{L}$ in both hard water (Ca $=1 \mathrm{mM})$ and soft water $(\mathrm{Ca}=0.04 \mathrm{mM})$.

\section{Acclimation}

Toxicological acclimation to cadmium may have occurred at the background and low chronic $\mathrm{Ca}$ exposures with $\mathrm{Cd}$. However, acclimation did not occur at the higher $\mathrm{Ca}$ concentrations, because subsequent challenge to $\mathrm{Cd}$ after the 30-d exposure did not yield significantly higher 96-h LC50 values compared with those of controls. The apparent acclimation at the low $\mathrm{Ca}$ levels may have resulted from selection for fitter fish, because total mortality was approximately $80 \%$ and approximately $40 \%$ for the background $+\mathrm{Cd}$ and low $+\mathrm{Cd}$ exposures, respectively, after the 30-d exposure to cadmium. However, mortality was minimal $(<10 \%)$ for the higher $\mathrm{Ca}-$ treated fish (Table 1). The chronic $\mathrm{Cd}$ exposure concentration of $2 \mu \mathrm{g} / \mathrm{L}$ (nominal) was, therefore, less than the threshold for acclimation at the higher $\mathrm{Ca}$ levels. Significant accumulation of Cd was observed in the gills of these fish (Fig. 1); however, the exposure concentration of approximately $2 \mu \mathrm{g} \mathrm{Cd} / \mathrm{L}$ may not have been great enough to induce morphological damage to the gills and, thereby, acclimation. McDonald and Wood [43] proposed a damage-repair hypothesis that describes an initial shock phase involved with metal exposure that results in morphological damage to the gills, followed by changes and repair of the gills with continued exposure to the metal, leading to acclimation of the fish. Lack of this damage repair may explain the observed acclimation of trout at the lower $\mathrm{Ca}$ exposures but not at the higher chronic $\mathrm{Ca}$ exposures to $\mathrm{Cd}$.

\section{Internal Cd distribution}

Although the diet had appreciable $\mathrm{Cd}(1.06 \mu \mathrm{g} / \mathrm{g})$, we are confident that the great majority of $\mathrm{Cd}$ accumulation observed in the present study came from the water, because the control fish on the same diet exhibited negligible $\mathrm{Cd}$ buildup in the tissues during the $30-\mathrm{d}$ period. Indeed, the most sensitive indicator of chronic waterborne $\mathrm{Cd}$ exposure appears to be tissue accumulation of the metal. Kidneys accumulated the greatest concentration of $\mathrm{Cd}$ during the 30-d exposure, followed by gills and liver (Fig. 1). Several other studies have demonstrated equal or greater concentrations of $\mathrm{Cd}$ (relative to gills or liver) in kidneys of chronically exposed trout. Benoit et al. [14] and Kumada et al. [38] showed that kidney Cd concentrations remained high once the fish were returned to $\mathrm{Cd}$-free water, 
indicating the importance of the kidney as a storage organ for Cd.

The protective effects of $\mathrm{Ca}$ against $\mathrm{Cd}$ uptake into the organs was observed for the gills, liver, and kidney, with decreased $\mathrm{Cd}$ accumulation at higher water $\mathrm{Ca}$ concentrations (Fig. 1). However, we cannot rule out the possibility that some of this apparent protective effect resulted from measured $\mathrm{Cd}$ levels in the medium and high treatments being less than nominal, whereas in the background and low treatments, such levels were substantially greater than nominal. Nevertheless, Wicklund and Runn [4] similarly showed the protective effects of $\mathrm{Ca}$ against $\mathrm{Cd}$ uptake with slower uptake of $\mathrm{Cd}$ into the gills with increasing water Ca levels $(0.2-5 \mathrm{mM})$, causing lower $\mathrm{Cd}$ accumulation in the liver and kidney. Verbost et al. $[41,42]$ demonstrated that $\mathrm{Cd}^{2+}$ and $\mathrm{Ca}^{2+}$ compete for the same apical channel in the initial uptake step into the gills, whereas the basolateral transports appear to differ. Cadmium noncompetitively inhibits the high-affinity $\mathrm{Ca}^{2+}$ ATPase, which moves $\mathrm{Ca}^{2+}$ across the basolateral membrane into the bloodstream. Pärt et al. [2] reported a strong, inverse relationship between water $\mathrm{Ca}^{2+}$ concentrations as great as $3 \mathrm{mM}$ and $\mathrm{Cd}$ uptake into perfused rainbow trout gills; however, $\mathrm{Cd}$ retention in gill tissue was not sensitive to water $\mathrm{Ca}$ and, therefore, was different from Cd transfer.

\section{Implications for biotic ligand modeling}

The biotic ligand model involves use of the fish gill, which is the primary site of toxic action, as a generalized biotic ligand for complexing metals $[13,28]$. Conditional equilibrium stability constants for the affinity of this biotic ligand for a particular metal, along with relevant water chemistry, are entered into aquatic geochemistry programs (e.g., MINEQL+) to predict metal binding to the gills $[44,45]$. The predicted accumulation by the gills correlates with the toxicity of the metal to the fish [46].

In our previous study, we demonstrated that the biotic ligand model could be successfully applied to fish in hard water [20]. In the present study, however, control fish $(260 \mu \mathrm{M} \mathrm{Ca})$ had much higher new gill Cd concentrations (higher $B_{\max }$ values; Table 2) compared with our earlier study in hard water [20]. This discrepancy in the number of gill Cd-binding sites between studies may result from size or batch differences in fish or from differences in feeding regime, which was a $1 \%$ daily ration in the present study versus $3 \%$ in the previous one. In the current study, fish were fed a submaximal ration of $1 \%$ body weight per day in the hope of revealing metabolic costs associated with chronic $\mathrm{Cd}$ exposure. Whatever the explanation for the differences in $B_{\max }$ values between studies, this creates problems when trying to apply the biotic ligand model to different sets of experiments. In our previous study [20], the maximum number of binding sites was similar to the fathead minnow value of $0.2 \mathrm{nmol} /$ fish or $2 \mathrm{nmol} / \mathrm{g}$ of gill from Playle et al. $[44,45]$. The present study yielded gill Cd-binding site numbers closer to that reported by Hollis et al. [47] for rainbow trout $(1 \mathrm{nmol} / \mathrm{fish}$ or $10 \mathrm{nmol} / \mathrm{g}$ of gill). Hence, the biotic ligand model would only be successful at predicting new $\mathrm{Cd}$ accumulation in the gills of the Ca-exposed fish from the present study (Fig. 5A) if the number of Cd-binding sites on the gill was increased.

For example, if the conditional stability constant for $\mathrm{Cd}$ binding to the gill $\left(\log K_{\mathrm{Cd} \text {-gill }}=8.6\right)$ from Playle et al. $[44,45]$ and the number of Cd-binding sites $\left(B_{\max }\right)$ on the gill $(1 \mathrm{nmol} /$ fish or $10 \mathrm{nmol} / \mathrm{g}$ of gill) from a different source, such as
Hollis et al. [47], were used in the biotic ligand model, we could successfully predict new $\mathrm{Cd}$ accumulation in the gills of the Ca-exposed fish. Interestingly, whereas the $\log K_{\text {Cd-gill }}$ value was derived for fathead minnow, the high $B_{\max }$ value of $10 \mathrm{nmol} / \mathrm{g}$, which is similar to the present data, was derived from work on rainbow trout [47]. In that study, the fish were fed once per day on a limited ration (L. Hollis, personal communication), as in the present study, pointing to feeding as the cause of the variation in $B_{\max }$. In our previous study [20], fish were fed a threefold higher ration (3\% per day as three daily meals). Possibly, fish on restricted ration may upregulate $\mathrm{Ca}^{2+}$ transport from the water to augment limited dietary calcium, thereby increasing the $B_{\max }$ for $\mathrm{Cd}^{2+}$ binding on the gills. However, other important factors, such as age and size of the fish, cannot be ruled out as possible explanations for the observed changes in the number of gill-binding sites between studies.

The biotic ligand model is able to predict $\mathrm{Cd}$ accumulation in control fish. However, for several reasons, the model cannot be used to predict gill $\mathrm{Cd}$ loading and toxicity in trout that are chronically exposed to $\mathrm{Cd}$. Both the $\log K_{\mathrm{Cd} \text {-gill }}$ and $B_{\max }$ values for new $\mathrm{Cd}$ were altered as a result of chronic $\mathrm{Cd}$ exposure, with the affinity decreasing and the site number increasing (Table 2). Furthermore, total cold Cd burden was increased during chronic exposure by approximately fourfold (4.2 and $2.5 \mu \mathrm{g} \mathrm{Cd} / \mathrm{g}$ for background and high Ca, respectively; Fig. 1) saturation of the $B_{\max }$ values ( 1.1 and $0.6 \mu \mathrm{g} \mathrm{Cd} / \mathrm{g}$ for background and high $\mathrm{Ca}$, respectively; Table 2) for acute toxicity. The acute toxicity threshold itself appeared to change as well, but not in proportion to changes in gill Cd-binding kinetics. In addition, it was necessary to use a radiotracer technique, rather than the cold technique described by Playle et al. $[44,45]$, to detect the small increases in new gill accumulation against the high background $\mathrm{Cd}$ pools accumulated in the gills during the chronic 30-d exposure (Fig. 1).

Scatchard analysis was applied to the kinetic binding curves for $\mathrm{Ca}$ and for $\mathrm{Ca}+\mathrm{Cd}$-exposed fish (Fig. 5), which resulted in conditional stability constants of $\log K_{\text {Cd-gill }}=5.8$ to 7.0 (Table 2), much lower than that of Playle et al. [44,45] for fathead minnows $\left(\log K_{\text {Cd-gill }}=8.6\right)$ but reasonably similar to that of controls from our previous study for hard water-exposed fish $\left(\log K_{\mathrm{Cd} \text {-gill }}=7.6\right.$; [20]). At least in part, the difference in our $\log K_{\mathrm{Cd} \text {-gill }}$ values compared with that of Playle et al. [44,45] results from the difference in methods for calculating conditional equilibrium stability constants. We calculated these values from Cd loading in gills of the fish, whereas Playle et al. [44,45] used competitive ligands to reduced $\mathrm{Cd}$ accumulation of gills, a method that is less sensitive to the competitive effects of $\mathrm{Ca}^{2+}$ and $\mathrm{H}^{+}$. In the present study, as the water $\mathrm{Ca}^{2+}$ concentrations increased, the affinity of $\mathrm{Cd}$ for the gill decreased (Table 2). Using the $\log K_{\text {Ca-gill }}$ value of 5.0 from Playle et al. [44,45], the $\log K_{\mathrm{Cd} \text {-gill }}$ value should theoretically move $0.6 \log$ units (i.e., $\log K_{\text {Cd-gill }}$ of 7.4 decreases to 6.8 ) as the water $\mathrm{Ca}$ increases from 260 to $1200 \mu \mathrm{M}$. This reduction is identical to the shift seen in the present study (7.0 to 6.3; Table 2), although the absolute values are slightly lower.

Trout that had been chronically exposed to $2 \mu \mathrm{g} \mathrm{Cd} / \mathrm{L}$ accumulated more new $\mathrm{Cd}$ in their gills compared with their respective $\mathrm{Ca}$ controls when exposed acutely to higher total Cd concentrations, ranging from 6 to $115 \mu \mathrm{g} / \mathrm{L}$ (Fig. 5B). This influence of chronic $\mathrm{Cd}$ exposure (increased uptake of new $\mathrm{Cd}$ by gills during high $\mathrm{Cd}$ exposure of trout previously chronically exposed to low levels of $\mathrm{Cd}$ ) was also evident in the longer-term (72-h) gill-binding exposure to radioactive ${ }^{109} \mathrm{Cd}$ 
(Fig. 6). These results are similar to those of our hard-water study [20], in which fish chronically exposed to 3 and $10 \mu \mathrm{g}$ $\mathrm{Cd} / \mathrm{L}$ had higher gill concentrations of new $\mathrm{Cd}$ with an acute exposure to $100 \mu \mathrm{g} \mathrm{Cd} / \mathrm{L}$ but lower gill concentrations if the acute exposure was only $10 \mu \mathrm{g} \mathrm{Cd} / \mathrm{L}$.

The affinity of the gills for $\mathrm{Cd}$ was reduced by chronic exposure to $2 \mu \mathrm{g} \mathrm{Cd} / \mathrm{L}$, whereas the number of binding sites increased (Table 2). These changes in gill-binding characteristics are in good agreement with our previous results [20], in which the affinity of the gill for $\mathrm{Cd}\left(\log K_{\mathrm{Cd} \text {-gill }}\right)$ decreased and the number of gill Cd-binding sites $\left(B_{\max }\right)$ increased with chronic sublethal $\mathrm{Cd}$ exposures in hard water. Alsop et al. [48] have similarly shown that the affinity of the gill for zinc ( $\mathrm{Zn})$ was consistently reduced by chronic acclimation to sublethal $\mathrm{Zn}$, and that $B_{\max }$ was greater for $\mathrm{Zn}$-exposed fish compared with controls. Gill $\mathrm{Zn}$ pool size was also much larger in soft water $\left(20 \mathrm{mg} / \mathrm{L}\right.$ as $\left.\mathrm{CaCO}_{3}\right)$ than in hard water $(120 \mathrm{mg} / \mathrm{L}$ as $\mathrm{CaCO}_{3}$ ) [48]. Thus, two metals, one essential ( $\left.\mathrm{Zn}\right)$ and one nonessential $(\mathrm{Cd})$, appear to be handled in similar ways by the gill during chronic exposure. During acute exposures, these two metals interfere with branchial $\mathrm{Ca}^{2+}$ uptake in freshwater fish, causing hypocalcemia $[41,42,49]$. Therefore, it seems likely that the binding sites for both metals are part of the branchial transport system for $\mathrm{Ca}$ (e.g., $\mathrm{Ca}$ channels or $\mathrm{Ca}-$ transporters), and that changes occurring in $\log K$ and $B_{\max }$ values as a result of chronic $\mathrm{Cd}$ or $\mathrm{Zn}$ exposure represent changes in the nature or expression of the proteins that, in some way, are involved in Ca uptake. Increases in $B_{\max }$ values likely reflect increases in the amount of protein available for transport, but the cause (or causes) of decreases in $\log K$ values is unknown. The molecular basis for these changes will be an exciting area for future research.

\section{CONCLUSIONS}

In conclusion, discrepancies are found in the maximum number of gill Cd-binding sites found in this study compared with those in earlier gill-binding studies [20,44,45], but our results are in agreement with those of Hollis et al. [47]. Therefore, difficulties exist in using the biotic ligand model as a tool for predicting toxic effects of $\mathrm{Cd}$ to fish at various water Ca concentrations. In addition, the acute toxicological threshold appears to change in an unpredictable manner as a result of acclimation in some instances but not in others. Furthermore, the adaptive changes that occur in the gills of fish that are chronically exposed to $\mathrm{Cd}$ cannot be easily incorporated into the model. Cold $\mathrm{Cd}$ concentrations in the gills increased during the 30- $\mathrm{d}$ exposure to $\mathrm{Cd}$, and these changes were accompanied by decreases in the affinity of the gill for $\mathrm{Cd}$ as well as by increases in the number of gill Cd-binding sites. These adaptive changes are currently not accounted for by the biotic ligand model. Until the discrepancies in $B_{\max }$ values between studies and changes in toxic threshold and in gillbinding characteristics with chronic $\mathrm{Cd}$ exposure can be resolved for the biotic ligand model, current chronic ambient water-quality criteria for $\mathrm{Cd}$ at different $\mathrm{Ca}$ concentrations are reasonable limits for protecting aquatic life. These regulations do not take water $\mathrm{Mg}^{2+}$ levels, DOM concentrations, and so on into consideration, but they are based on water hardness, which is the most influential factor on Cd uptake and toxicity. Recommended Canadian water quality guidelines for cadmium $(0.2-1.3 \mu \mathrm{g} \mathrm{Cd} / \mathrm{L}$ for a hardness range of $20-120 \mathrm{mg} / \mathrm{L}$ as $\mathrm{CaCO}_{3}$ ) [24] are currently set at $\mathrm{Cd}$ concentrations well below the chronic level $(2 \mu \mathrm{g} \mathrm{Cd} / \mathrm{L})$, which caused substantial fish mortality at the various water Ca concentrations in the present study. However, further research is needed to determine whether these limits for the protection of freshwater life exposed chronically to $\mathrm{Cd}$ are appropriately protective or overprotective, particularly on a site-specific basis.

Acknowledgement-This work was funded by the Natural Sciences and Engineering Research Council of Canada Strategic Grants Program, International Copper Association, Falconbridge, International Lead Zinc Research Organization, and Cominco. We thank Jeff Richards, Richard Playle, and Peter Chapman for helpful input.

\section{REFERENCES}

1. McCarty LS, Henry JAC, Houston AH. 1978. Toxicity of cadmium to goldfish, Carassius auratus, in hard and soft water. $J$ Fish Res Board Can 35:35-42.

2. Pärt P, Svanberg O, Kiessling A. 1985. The availability of cadmium to perfused rainbow trout gills in different water qualities. Water Res 19:427-434.

3. Pascoe D, Evans SA, Woodworth J. 1986. Heavy metal toxicity to fish and the influence of water hardness. Arch Environ Contam Toxicol 15:481-487.

4. Wicklund A, Runn P. 1988. Calcium effects on cadmium uptake, redistribution, andelimination in minnow, Phoxinus phoxinus, acclimated to different calcium concentrations. Aquat Toxicol 13: 109-122.

5. Spry DJ, Wiener JG. 1991. Metal bioavailability and toxicity to fish in low-alkalinity lakes: A critical review. Environ Pollut 71: 243-304.

6. Davies PH, Gorman WC, Carlson CA, Brinkman SR. 1993. Effect of hardness on bioavailability and toxicity of cadmium to rainbow trout. Chem Speciat Bioavailab 5:67-77.

7. Carrol JJ, Ellis SJ, Oliver WS. 1979. Influences of hardness constituents on the acute toxicity of cadmium to brook trout (Salvelinus fontinalis). Bull Environ Contam Toxicol 22:575-581.

8. McDonald DG, Reader JP, Dalziel TRK. 1989. The combined effects of $\mathrm{pH}$ and trace metals on fish ionoregulation. In Morris R, Taylor E, Brown D, eds, Acid Toxicity and Aquatic Animal. Cambridge University Press, London, UK, pp 221-242.

9. Calamari D, Marchetti R, Vailati G. 1980. Influence of water hardness on cadmium toxicity to Salmo gairdneri Rich. Water Res 14:1421-1426.

10. Wright DA. 1980. Cadmium and calcium interactions in the freshwater amphipod Gammarus pulex. Freshw Biol 10:123-133.

11. Pagenkopf GK. 1983. Gill surface interaction model for tracemetal toxicity to fishes: Role of complexation, $\mathrm{pH}$, and water hardness. Environ Sci Technol 17:342-347.

12. Hunn JB. 1985. Role of calcium in gill function in freshwater fishes. Comp Biochem Physiol 82:543-547.

13. Meyer JS. 1999. A mechanistic explanation for the $\ln ($ LC50) vs $\ln$ (hardness) adjustment equation for metals. Environ Sci Technol 33:908-912.

14. Benoit DA, Leonard EN, Christensen GM, Fiandt JT. 1976. Toxic effects of cadmium on three generations of brook trout (Salvelinus fontinalis). Trans Am Fish Soc 105:550-560.

15. Giles MA. 1984. Electrolyte and water balance in plasma and urine of rainbow trout (Salmo gairdneri) during chronic exposure to cadmium. Can J Fish Aquat Sci 41:1678-1685.

16. Pratap HB, Fu H, Lock RAC, Wendelaar Bonga SE. 1989. Effect of waterborne and dietary cadmium on plasma ions of the teleost Oreochromis mossambicus in relation to water calcium levels. Arch Environ Contam Toxicol 18:568-575.

17. Fu H, Steinebach OM, van den Hamer CJA, Balm PHM, Lock RAC. 1990. Involvement of cortisol and metallothionein-like proteins in the physiological responses of tilapia (Oreochromis mossambicus) to sublethal cadmium stress. Aquat Toxicol 16:257270.

18. Pratap HB, Wendelaar Bonga SE. 1993. Effect of ambient and dietary cadmium on pavement cells, chloride cells, and $\mathrm{Na}^{+} / \mathrm{K}^{+}$ATPase activity in the gills of the freshwater teleost Oreochromis mossambicus at normal and high calcium levels in the ambient water. Aquat Toxicol 26:133-150.

19. Iger Y, Lock RAC, van der Meij JCA, Wendelaar Bonga SE. 1994. Effects of water-borne cadmium on the skin of the common 
carp (Cyprinus carpio). Arch Environ Contam Toxicol 26:342350 .

20. Hollis L, McGeer JC, McDonald DG, Wood CM. 1999. Cadmium accumulation, gill $\mathrm{Cd}$ binding, acclimation, and physiological effects during long term sublethal $\mathrm{Cd}$ exposure in rainbow trout. Aquat Toxicol 46:101-119.

21. Sauter S, Buxton KS, Macek KJ, Petrocelli SR. 1976. Effects of exposure to heavy metals on selected freshwater fish: Toxicity of copper, cadmium, chromium and lead to eggs and fry of seven fish species. EPA 440/5-85-001. U.S. Environmental Protection Agency, Duluth, MN.

22. Alabaster JS, Lloyd R. 1982. Water quality criteria for freshwater fish, 2. Food and Agriculture Organization of the United Nations, Butterworths, London, UK, pp 221-251.

23. U.S. Environmental Protection Agency. 1986. Quality criteria for water. EPA 440/5-85-001. Office of Water Regulations and Standards, Washington, DC.

24. Canadian Council of Ministers of the Environment. 1995. Canadian Water Quality Guidelines. Winnipeg, MB, Canada.

25. Renner R. 1997. A better understanding of how natural waters inhibit metal uptake may change current regulatory limits. Environ Sci Technol 31:466-468.

26. Bergman HL, Dorward-King EJ. 1997. Reassessment of metals criteria for aquatic life protection: Priorities for research and implementation. Proceedings, SETAC Pellston Workshop on Reassessment of Metals Criteria for Aquatic Life Protection, Pensacola, FL, USA, February 10-14, 1996, p 114.

27. Playle RC. 1998. Modelling metal interactions at fish gills. Sci Total Environ 219:147-163.

28. Meyer JS, et al. 1999. Binding of nickel and copper to fish gills predicts toxicity when water hardness varies, but free-ion activity does not. Environ Sci Technol 33:913-916.

29. Mount DI, Brungs WA. 1967. A simplified dosing apparatus for fish toxicology studies. Water Res 1:21-29.

30. McDonald DG, McFarlane WJ, Milligan CL. 1998. Anaerobic capacity and swim performance of juvenile salmonids. Can J Fish Aquat Sci 55:1198-1207.

31. Hogstrand C, Wilson RW, Polgar D, Wood CM. 1994. Effects of zinc on the kinetics of branchial calcium uptake in freshwater rainbow trout during adaptation to waterborne zinc. J Exp Biol 186:55-73.

32. Finney DJ. 1971. Probit Analysis, 3rd ed. Cambridge University Press, New York, NY, USA.

33. Hollis L, Burnison K, Playle RC. 1996. Does the age of metaldissolved organic carbon complexes influence binding of metals to fish gills? Aquat Toxicol 35:253-264.

34. Reid SD, McDonald DG. 1991. Metal binding activity of the gills of rainbow trout (Oncorhynchus mykiss). Can J Fish Aquat Sci 48:1061-1068.

35. Schecher WD, McAvoy DC. 1994. MINEQL+User's Manual. Environmental Research Software, Hallowell, ME, USA.

36. Zall DM, Fisher MD, Garner QM. 1956. Photometric determination of chlorides in water. Anal Chem 28:1665-1678.

37. Giles MA. 1988. Accumulation of cadmium by rainbow trout, Salmo gairdneri, during extended exposure. Can J Fish Aquat Sci 45:1045-1053.

38. Kumada H, Kimura S, Yokote M. 1980. Accumulation and biological effects of cadmium in rainbow trout. Bull Jpn Soc Sci Fish 46:97-103.

39. Reid SD, McDonald DG. 1988. Effects of cadmium, copper, and low $\mathrm{pH}$ on ion fluxes in the rainbow trout, Salmo gairdneri. Can $J$ Fish Aquat Sci 45:244-253.

40. Scherer E, McNicol RE, Evans RE. 1997. Impairment of lake trout foraging by chronic exposure to cadmium: A black-box experiment. Aquat Toxicol 37:1-7.

41. Verbost PM, Flik G, Lock RAC, Wendelaar Bonga SE. 1987. Cadmium inhibition of $\mathrm{Ca}^{2+}$ uptake in rainbow trout gills. Am J Physiol 253:216-221.

42. Verbost PM, Van Rooij J, Flik G, Lock RAC, Wendelaar Bonga SE. 1989. The movement of cadmium through freshwater trout branchial epithelium and its interference with calcium transport. J Exp Biol 145:185-197.

43. McDonald DG, Wood CM. 1993. Branchial mechanisms of acclimation to metals in freshwater fish. In Rankin JC, Jensen FB, eds, Fish Ecophysiology. Chapman and Hall, London, UK, pp 297-321.

44. Playle RC, Dixon DG, Burnison K. 1993. Copper and cadmium binding to fish gills: Modification by dissolved organic carbon and synthetic ligands. Can J Fish Aquat Sci 50:2667-2677.

45. Playle RC, Dixon DG, Burnison K. 1993. Copper and cadmium binding to fish gills: Estimates of metal-gill stability constants and modelling of metal accumulation. Can J Fish Aquat Sci 50: 2678-2687.

46. MacCrae RK, Smith DE, Swoboda-Colberg N, Meyer JS, Bergman HL. 1999. Copper binding affinity of rainbow trout (Oncorhynchus mykiss) and brook trout (Salvelinus fontinalis) gills. Environ Toxicol Chem 18:1180-1189.

47. Hollis L, Muench L, Playle RC. 1997. Influence of dissolved organic matter on copper binding, and calcium on cadmium binding, by gills of rainbow trout. J Fish Biol 50:703-720.

48. Alsop DH, McGeer JC, McDonald DG, Wood CM. 1999. Assessing the costs and consequences of chronic waterborne zinc exposure to juvenile rainbow trout in hard and soft water. Environ Toxicol Chem 18:1014-1025.

49. Spry DJ, Wood CM. 1985. Ion flux rates, acid-base status and blood gases in rainbow trout, Salmo gairdneri, exposed to toxic zinc in natural soft water. Can J Fish Aquat Sci 42:1332-1341. 